\title{
Forays into Ukrainian Canadian Folklore Today: A Snapshot from Winnipeg, Manitoba (Canada)
}

\author{
Robert B. Klymasz \\ Winnipeg, Manitoba \\ Canada
}

Having retired in 2000 from the Canadian Museum of Civilization just outside Ottawa in Gatineau, Quebec, I relocated to the city of Winnipeg Manitoba -- the historic hub of Ukrainian life in Canada. Once again, I found myself in a city where it's commonly assumed that everybody is either a Ukrainian or married to one. This time, however, Winnipeg was not just a stopover on the way to promising relic areas further west -- towns like Dauphin, Yorkton, Vegreville and all those surrounding rural areas dripping with Ukrainian folklore.(1) I was in Winnipeg to stay. In retirement my youthful energy and expense account had disappeared and those summer expeditions were now history. Winnipeg was to become my permanent home.

Nonetheless, once a folklorist, always a folklorist. That being the case, it was difficult to ignore Ukrainian folklore phenomena seemingly crowding in on me wherever I turned. It became evident that Winnipeg's Ukrainian population was as driven by folkloric interests and activities as any community. Although the folklore was there, I was poorly prepared to grapple with the dynamics of a novel situation. The old markers I had learned to look for, the onion domed churches and outdoor toilets on the open prairie, were simply not part of Winnipeg life. This was an urban setting, and yet it was permeated by the same "real" lore that I had recorded many years earlier in a rural environment. Expression not oral; it was through modern media, but there it was, full of the folklore that I knew. My initial resistance to calling this folklore gave way to acceptance and I came to realize that all these new phenomena, including totally non-traditional events like Ukrainian flag-raising ceremonies, were modern folklore that both warranted and deserved serious attention and study. It is likely that many of the following findings, though largely the results of my armchair fieldwork, are applicable to the folklore of other Ukrainian urban communities across North America.

Language Loss

This marks the most dramatic aspect of Winnipeg's Ukrainian folklore complex. Although Ukrainian no longer lives as a viable 
medium for everyday verbal intercommunication, the language nonetheless functions as a "heritage language" and, as such, is maintained as a marker of traditional authenticity and quasi-loyalty. Canadian Ukrainian is frequently garbled and twisted. Newspaper obituaries in the local leading English language daily mourn the passing of Winnipeg Ukrainians and frequently end with three words: "Vichnaya Pam Yat" [instead of vichnaja pamjat' - eternal memory]. Radio commercials for a local meat shop, Karpaty Meats, tend to sound like "Car Patty Meats". Of course macaroni songs continue to titillate the public and dominate the bulk of zabava radio programming in the region. The d.j. regularly selects "golden oldies" that include a particular sound recording of a traditional Ukrainian murder ballad delivered in rollicking fashion by a polka band. Everyone seems utterly unaware of the ballad's sinister storyline in which a maiden is tied to a tree and set on fire by her malicious abductors.

\section{Surfing obituaries}

Aside from the anomalies cited above, the grass-roots "family notices", that is obituaries, memorials, and sundry announcements published in the Winnipeg Free Press provide a more interesting source of data and Saturday's weekend issue is especially rich with such material. Surfing newspaper obituaries on a daily basis can become a preoccupation for any folklorist. These often constitute narratives with epic overtones. The following extract from a ten-paragraph obituary (published August 21,2010) constitutes a synopsis of the original version and outlines the life story of a centenarian, William Pylypchuk, also known as Bill Phillips.

Bill was born in 1909 in East Galicia, Austria, and arrived in Canada with his parents in 1912, settling in Manitoba. As a young boy, Bill loved to act, sing and dance and thoroughly enjoyed "having adventures" with his buddies in and around the Winnipeg area.

In 1940, Bill joined the Canadian Army and saw active duty in France and Germany. After D-Day, he returned to Canada where he met and married "an English girl named Nelma". Following the birth of a son in Ajax, Ontario, the family moved to Nelma's homeland and "settled in the quiet, picturesque village of Eyethorne, near Dover."

In 1983, after the death of his wife, Bill returned to Winnipeg where he made a home for himself once again. He fulfilled his love of singing by taking an active role in the Age and Opportunities Senior Choir until he suffered a stroke... 
Bill's obituary can only be "appreciated" as a folkloric document when compared to other obituaries (non-Ukrainian as well as Ukrainian). Such comparison reveals dichotomies that govern this corpus and bring it into a relationship with a more archaic version of the Ukrainian lament tradition. Here Bill is remembered as a "first-waver," a man who experienced the initial rush of Ukrainian immigrants to Canada a century ago. In such obituaries, pastimes are often mentioned and Bill's singing and other musical pursuits appear here. Were this the obituary of a woman, the text would likely be different. Deceased Ukrainian "babas" are invariably revered for their talents as cooks and gardeners. The way the year and place of birth are given here is significant because the lives of Ukrainians émigrés arriving in Canada after the Second World War, the so-called "D.P. third wavers," are commemorated quite differently (2). Religious affiliation, usually revealed by details concerning the last rites and burial site, is also important and given in a formulaic way. An annotated motif index to this commemorative material, should it ever be compiled, would reveal the structural operatives that characterize the nature of these newspaper laments, laments that are part of Canadian and diasporic Ukrainian folklore in the $21^{\text {st }}$ century.

\section{Popular Onomastics}

The continuing popularity of Ukrainian folkdance has led to a proliferation of "clubs", "ensembles", "schools", and "academies." The 2010 version of Winnipeg's annual city-wide two-week-long "Folklorama" extravaganza featured twenty-five such groups. Each performing dance group has a name, and on the basis of a sampling limited to Folklorama, one can see the importance of the gender as a principle governing name choice. The majority of dance groups have adopted feminine nouns to serve as their names, and these reflect a pronounced focus on nature (pryroda in Ukrainian and also feminine). Examples include: "Reechka" [little river], "Zorya" [star], "Fialka" [violet flower], "Troyanada" [rose-flower], "Vesna" [spring], "Zirka" [star], and "Zaavarooka" [sic] [whirlwind]. There are some folkloric names such as "Rusalka" [mermaid], "Slava!" [glory / Gloria?], and "Sopilka" [flute, reed-pipe]. Few groups carry male names. Winnipeg examples are "Barvinok" [periwinkle], "Rozmai" [rosemary], and "Romanetz" [chamomile]. Only one dance group took on a neuter noun, "Selo", [village] as its name. Unfortunately one English daily referred to this group as the "Salo" [fatback] Ukrainian dancers. As an adjunct to the above naming practices, it is telling that most of these dance ensembles 
have dropped "folk" but retained "Ukrainian" as their preferred descriptor. I read this as a tacit attempt to distinguish this genre of dance and possibly elevate it to level of other genres such as ballet, contemporary dance, and hip-hop.

\section{Foodways}

Winnipeg's supermarkets and assorted grocery outlets carry a constant supply of perogies from near and far. There are typically frozen in packages of a dozen, or its multiples. Many church groups, including Anglicans, commonly hold public perogy dinners as fund raising events. The perogy season, which runs from fall to spring, is utilized for fund raising purposes by other religious and non-religious groups, both with and without a Ukrainian affiliation. The ladies at Winnipeg's Holy Trinity Ukrainian Orthodox Cathedral are famous for their monthly "all you can eat perogies" day-long marathons. Most commercial eateries capitalize on the popularity of perogies. There are even striking culinary experiments like perogy pizzas and perogy sandwiches.(3) Having entered the culinary mainstream, the perogy rules triumphantly, and Winnipeg's own Orysia Tracz, has become the undisputed authority on this phenomenon.

\section{Calendar shifts}

According to advertisements published in the continent's leading English-language Ukrainian newspaper The Ukrainian Weekly, "being Ukrainian" can be defined on a month-by-month basis by certain calendar customs and holidays. These range from "Malanka" in January to "Koliada" [traditional caroling] in December. Winnipeg's variant of "being Ukrainian" features two Christmases: "English Christmas" (on December $25^{\text {th }}$ ) and "Ukrainian Christmas" (on January $7^{\text {th }}$ ).(4) The latter is commonly deemed less harried and more "true to the spirit or meaning of Christmas." By far, however, the most significant modification of the Canadian calendar is the universal acceptance of Malanka, as a riproaring celebration that marks Ukrainian New Year's Eve (January $13^{\text {th }}$ ) and/or New Year's Day (January $14^{\text {th }}$ ). This holiday, due to its position in the month of January, strategically situated between the month of December and mainstream Christmas and the month of February with its mainstream St. Valentine's Day celebrations, brings a measure of joy and warmth in the middle of the invariably harsh Winnipeg winter. It offers some relief to the post-Christmas doldrums that would otherwise permeate the city's mentality. 
The "blessing of Easter baskets" continues to hold its widespread popularity and some parishes holding basket-blessing rituals "every hour on the hour" in overflowing church basements and auditoriums on the Saturday before Easter Sunday. As for the baskets themselves, they often depart from the old traditions of what an Easter basket should look like and what it should contain. Many take on the appearance of summery picnic baskets, complete with a bottle of wine.

The jollity factor ascribed to Ukrainian traditions is most evident in the widespread popularity of "the social", a celebration that developed out of old Ukrainian wedding practices. This event is now traditional in its own right and acknowledged as such by a special entry in The Encyclopedia of Manitoba (2007). Unlike the aforementioned festive events that are calendar-specific, the pre-nuptial "social", like most weddings and all funerals, can take place any time of the year. The social is usually organized by and/or for a couple engaged to be married. Food, music, and drink are the principal attractions. Attendees do not necessarily need to know the engaged couple and tickets to the event are sold to anyone who would like to participate and have a good time. Ticket sales then serve as a means of providing the couple with giftmoney. The above is but a skeletal outline of the social and there many variations to this practice.

In keeping with their established reputation throughout western Canada, Ukrainian traditions are commonly lauded for a certain joie de vivre. There seems to be a folk belief that Ukrainians are characterized by a general fondness for merry-making and that their events are more exuberant than those of other peoples. The exuberance attributed to Ukrainian celebrations is seemingly absent from other traditions. Unfortunately, folklorists have yet to investigate this particular belief in depth, especially since it departs from established models of folkloristic investigations. Especially telling, in this regard, is the function of "Malanka" and "the social" as mentioned above.

\section{Some final observations}

Previous research has shown that language loss within a heritage community is balanced by a heightened emphasis on residual elements. The transition is driven by a process of codification and standardization, along with "search-and-rescue" operations. Traditional foodways, for example, are elevated to "cuisine" status and transmitted via written recipes and a plethora of Ukrainian cookbooks (invariably written in English). Ukrainian folk dance ensembles commonly discard the word 
"folk" and market themselves as simply "Ukrainian dance" groups in a tacit effort to focus on genre rather than ethnicity, thereby seeking parity with ballet and hip-hop.

Language loss with its attendant ramifications also provides strong incentive for some to take serious note of their family trees. Genealogy is now a flourishing pastime pushing many Canadians of Ukrainian descent to research their past. Many hope to find at least a modicum of noble Cossack blood as a part of their pedigree and finding a coat of arms is doubly desirable. Many face formidable challenges as they painstakingly track, trace, pinpoint, and hopefully certify the origins. Finding records of ancestors who may well have been illiterate poses a special challenge.

Among the various manifestations of folk tradition, visual signifiers have become specialized pursuits in the hands of dedicated scholars and hobbyists alike. Portables like Easter eggs are, of course, a prime example of such endeavors. More recently, with the help of technology, Ukrainian churches throughout the western provinces are being meticulously documented and placed onto "the web" for universal consumption on demand.

Traditional attire constitutes a special "problem" since the living human body is the object of all dress and complementary adornment. Consequently and quite naturally, most devotees of the Ukrainian folk costume see a given costume ensemble (and / or its various parts and accoutrements) as inextricably tied to a human torso. In keeping with this valid perception, institutions and enthusiasts who collect and store items of apparel, prefer to show their costume pieces on mannequins or in an even more dynamic manner. Some collectors have parade participants were their costumes. Some have staged fashion shows where live, but mute, "models" simply walk down a runway and show off the costumes they wear for onlookers to examine and admire at close-range. A commentary in English generally accompanies such re-enactments of Old Country Ukrainian folk apparel.

\section{NOTES}

1 While he worked for the Museum of Civilization, Robert Klymasz did extensive fieldwork among the Ukrainians on the prairies. His work resulted in:

Sviéto: celebrating Ukrainian-Canadian ritual in east central Alberta through the generations, The Ukrainian folk ballad in Canada (musical transcriptions by Kenneth Peacock), Folk narrative among Ukrainian- 
Canadians in western Canada, Ukrainian folklore in Canada: an immigrant complex in transition, among other publications (ed.).

2 D. P. is a contraction of displaced person. It refers to Ukrainians uprooted by the Second World War. Immigrants to North America who came after the Second World War are called third-wavers because the first big wave of Ukrainian immigration was the one that came in the late 1800 s and the beginning of the 1900s. This group came in response to poor economic conditions in Europe (especially the Austro-Hungarian Empire) and promises of economic opportunity in the West. Canadian offers of cheap land in the prairies were especially attractive. The second wave came after the First World War.

3 It should be noted that pyrohy are dumplings typically stuffed with a mixture of mashed potatoes and cheese. Thus the use of these as a meat substitute in pizzas and sandwiches, especially by meat-loving nonUkrainians, is unexpected.

4 The January $7^{\text {th }}$ holiday is Christmas according to the Julian calendar, the so-called Old Style calendar used in many Ukrainian churches. 